PART II

Western Continental Europe 


\title{
The French Juvenile Justice System ${ }^{1}$
}

\author{
Anne Wyvekens
}

\section{INTRODUCTION}

Current French law on juvenile justice has a long story. It originated in the immediate aftermath of World War II and is still governed by an ordinance of 2 February 1945 . In this paper we would like to consider especially the most recent part of this story and to examine whether and to what extent the French juvenile justice system possibly shows a trend to become more repressive. Its founding principles - specialised jurisdiction, mitigated criminal responsibility due to age ${ }^{2}$ and priority placed on educational rather than law enforcement measures - were indeed at the beginning of the 2000s at the heart of a virulent debate, with the ministries of Justice and the Interior on opposing sides of the issue. Although several laws, including one adopted on 9 September 2002, introduced changes that could be interpreted as a movement towards a more punitive approach to juveniles, the original principles were nevertheless officially reaffirmed.

\section{GLOBAL OVERVIEW OF DELINQUENCY TRENDS IN FRANCE}

The common discourse in France over the past years holds that juvenile delinquency is on the rise and that young delinquents are becoming younger and more violent. A debate has been launched on these assertions, not so much to discount the statistics themselves as to question whether or not they are sufficiently wellgrounded to substantiate the policies they are presumed to legitimise. Although the limits and biases of statistical approaches are well known, there is also a limit

${ }^{1}$ I extend my thanks to Ms Flavie Le Sueur, deputy prosecutor for minors at the Pontoise Tribunal de Grande Instance, for her assistance in preparing this report.

${ }^{2}$ Following art. 1 of the ordinance of 2 February 1945, minors (i.e., young under 18) are to be judged by juvenile courts, not by ordinary ones. By way of comparison, on a total population of 62 millions inhabitants, 23,8\% are under the age of 20 (INSEE Première, $\mathrm{n}^{\circ} 1001$, janvier 2005).

If educational measures are supposed to be administered in priority to these minors, different ages have to be taken into account in order to determine what kind of measures will be choosen. An "educative sanction" can be taken for a minor aged 10 (see below), a sanction can be pronounced against a minor aged 13 and, on the contrary, young between 18 and 21 can request to receive educational measures like minors. 
as to how far they can be questioned. On the whole, any reservations tend to concern the extent of the evolution rather than whether it exists or not.

Several sources are now available in France. The first is a long-standing institutional source: figures from the police and judicial system (Aspects de la délinquance . . . 2003; Ministère de la Justice, 2003). Another more recent and as yet relatively undeveloped source is surveys on self-reported delinquency. Various forms of monitoring agencies have also come into being over recent years.

\subsection{Figures from the Police and Judicial System}

As summarised in a 2002 report prepared for the Senate (Commission d'enquête sur la délinquance des mineurs, 2001-2002: 163 \& sq.), ${ }^{3}$ the number of offences where minors were placed under suspicion rose $20.4 \%{ }^{4}$ from 1977 to 1992, and $79 \%$ from 1992 to $2001 .{ }^{5}$ A sharp rise observed from 1994 (17.7\% increase over 1993 figures $^{6}$ ) continued at the same rhythm over the ensuing years: $15.4 \%$ higher in $1995,{ }^{7} 13.9 \%$ in $1996,{ }^{8} 7.3 \%$ in $1997,{ }^{9}$ and $11.2 \%$ in $1998 .{ }^{10}$ After a slight drop observed in 1999 (down $0.81 \%{ }^{11}$ ), the figures rose again, but more moderately, with an increase of $2.86 \%$ in 2000 and $1 \%$ in 2001. These last figures (published in 2004) reflect a stabilisation, or even a slight decrease in the number of offences involving minors.

\subsection{Self-reported Delinquency}

Self-report delinquency surveys, a common methodological tool in the AngloAmerican countries for a number of years now, have been used in France in a systematic and detailed manner only since the late 1990s (Bègue, 2000; Roché 2000,2001 ), and as yet not at the national level. These surveys provide information on the risk factors of delinquency, profiles of the perpetrators and criminal processing of the infractions. The study conducted by Sebastian Roché in two cities points to "overactive groups" of delinquents: $5 \%$ of the 13 - to 19 -year-olds in one city committed between $55 \%$ to $88 \%$ of the crimes (according to the type of crime). Roché's findings also support the hypothesis of an overrepresentation of delinquency among youths of foreign origin. The study shows that school

\footnotetext{
${ }^{3}$ The most recent figures are also annexed to this report.

${ }^{4}$ Rising from 85151 to 98864 .

${ }^{5} 177010$ minors placed under suspicion in 2001.

${ }^{6} 109338$ minors placed under suspicion.

${ }^{7} 126233$ minors.

${ }^{8} 143824$ minors.

${ }^{9} 154437$ minors.

${ }^{10} 171787$ minors.

${ }^{11} 170387$ minors.
} 
drop-out is a reliable indicator of delinquent behaviour. Lastly, the study shows that criminal proceedings are rare: the delinquent is seldom arrested.

\subsection{Monitoring Boards for Delinquency and School Violence}

Another source of quantitative information on juvenile delinquency comes from various "monitoring boards". The National French Delinquency Monitoring Board (Observatoire national de la délinquance), established by the Interior Ministry in 2003, aims to pull data together from various sources in order to complete police statistics, the traditional source of information. Juvenile delinquency, however, does not appear to be one of the Board's current priorities. On the other hand, a whole new series of local agencies monitoring school violence and truancy, as well as partnerships formed to pool data on juvenile delinquency are starting to yield interesting indicators.

\section{THE PREVENTION OF DELINQUENT BEHAVIOUR}

Crime prevention in France is an area closely associated with the general issue of minors. French-style prevention is known for its primarily social and educational dimension, unlike the notion that prevention may have in Anglo-American cultures where the situational component prevails. Crime prevention experienced a renaissance in the early 1980s on the basis of the work done by a commission of mayors of medium and large cities, the now-famous "Bonnemaison report" (Commission des maires sur la sécurité, 1982). This report promoted what would later be termed local public safety policies or partnerships around the authority of the mayor, under the banner of prevention. While the institutions and partnerships that were set up following this report focus on crime prevention in the broad sense of the term, their preferred field of action is juvenile delinquency, since that still relates to social forms of prevention.

\subsection{Early Prevention}

France as yet has hardly developed practices for early prevention of juvenile delinquency. It is easy to understand how delicate the process can be: can we reasonably expect to early identify risk factors enabling us to undertake action with young children? And the corollary refers to the risk this type of policy involves: that of diluting the notion of crime prevention (for example "antisocial behaviour"), and the more onerous stigma caused when the services and agencies become involved long before any delinquent act has been committed. An experiment along these lines is presently under way in the Paris region. The early prevention actions presently conducted in France are oriented towards assisting the parents and helping them exercise their authority. One example 
is the "parent centres" that have sprung up in the framework of Local Security Contracts (contrats locaux de sécurité, CLS); their overall objective is to help parents by advising them or referring them to other agents (especially psychologists) who can provide support in coping with their children.

\subsection{Special Prevention}

Until the early 1980s, prevention of juvenile delinquency was the almost exclusive domain of specialised educators who worked in "prevention clubs" in the street in contact with youth, in the attempt to build an individualised relationship. These prevention clubs, (which can still be found), have been criticised against the background of the increase in juvenile delinquency and the fact that it starts at ever younger ages. Their workers are seen as ineffective, or even guilty of a certain laxness towards their young protégés. It is also hard for them to find a place in new partnership arrangements, particularly when they must deal with "repressive" agencies, the police and justice system.

\subsection{New forms of "Social" Prevention}

Several types of actions focussing on youth were designed following the "Bonnemaison report" - at first in the framework of City Councils for Crime Prevention (conseils communaux de prévention de la délinquance, CCPD), and then under the Local Security Contracts. These actions consist of community initiatives, extra-curricular and general recreational activities, proposed mainly to youth in the most troubled neighbourhoods and organised in the context of "urban" policy. These campaigns are increasingly organised in partnerships, associating a broad range of agents consisting of educators, social workers, the police, municipal services and occasionally businesses. They include, for example, school monitoring, national education relay services and police recreational centres. ${ }^{12}$

Although "school monitoring" (veille éducative) is not explicitly linked to preventing delinquency, it is nevertheless closely tied to endeavours to distance youths from occasions of delinquency and to preserve public order. The aim is "in urban policy priority sites" to "mobilise and co-ordinate educational and social agents, professionals involved in public health and social integration to identify youths who have dropped out of school or are in danger of dropping out, and to propose educational and integration solutions." 13 The programme takes the form of local partnerships having as a basic principle to develop responses that are educational rather than law enforcement-oriented, and to

${ }^{12}$ For more recent examples, see the summary of local actions" published by the Délégation interministérielle à la Ville (2004).

${ }^{13} \mathrm{Cf}$. the letter from the Prime Minister on 21 January 2002 referring to a joint circular by the Ministries of National Education and Urban Policy of 11 December 2001. 
build a network in which all the agents, including the national education system, are on an equal footing. The mayor is designated as the system's "guarantor". Its action modes are to implement tutoring and mentoring by volunteers outside the school environment: local residents, members of the city council, elected parent representatives.

Along the same lines, the national education system has initiated a series of "relay services" for young dropouts. Although the form can vary depending on the school level and age of the youths, the duration (from a few weeks to a whole school year) and other aspects, they share the common aim to offer "a temporary solution adapted to [students] who are in danger of school marginalisation or have already dropped out of school" (Ministère de l'Education nationale, 2003). The various services are based on volunteering: by the youths themselves, families and the instructors. The intention is to provide a stable context and behavioural limits, and to exert authority but without imposing sanctions. The activities are varied (such as calling on outside participants such as artists). The youth is not seen as a student, but as someone who needs help "to situate himself as a student". The objectives are "a type of learning different from that which occurs in school" and "reconciling youths with the constant presence of an adult". Since the relays are partnerships, the Legal Child Protection Service (Protection judiciaire de la jeunesse-PJJ) (see below) was closely associated with the programme's design and is represented on the board of admissions. However, it is not involved in the daily operation of the classes and workshops, which is handled by the national education system together with other partners (child psychiatrists, youth centres, etc.). As regards the "results", statistics after nine years show that approximately $70 \%$ of the youths returned to school. As for "real" results, that is whether the youths who return to school actually graduate, something has to change in the school system itself to achieve full success.

Another novelty related to the prevention policy is various schemes to get the police involved. Police officers have begun to invest their time in recreational, sports or cultural activities for youths. They organise these projects either in the framework of "summer prevention campaigns" (opérations prévention été, OPE), now referred to as "City-Life-Holiday" ("Ville-Vie-Vacances", VVV), coordinated by the Ministry of Youth and Sports, or else in the framework of Youth Recreational Centres (centres de loisirs des jeunes, CLJ) which are run by the national police service itself.

\subsection{The Question of Assessment}

Assessment is not France's strong point. Experiments are rarely evaluated, and it is even rarer to draw lessons when an evaluation is made. As for evidence-based programmes, the French are even less acquainted with this method. 


\section{POLICE INTERVENTION}

\subsection{Specialised Police}

A 1998 parliamentary report on "responses to juvenile delinquency" (Lazerges \& Balduyck, 1998) highlighted two points: that the police forces did not have a clear vision of the State's policy on minors, and that they lacked specialisation in dealing with juvenile delinquents. Although "juvenile brigades" do indeed exist, they mainly deal with minors who are victims. The report cited various explanations for this situation. Some were "negative" choices: not enough staff available, and little taste for a specialisation that police functionaries do not consider as prestigious. Other arguments were more "positive": both minors and adults are involved in the same crimes, juvenile delinquency is becoming diversified making it hard to determine the criteria for such a specialisation.

A second report, prepared in 2002, observed that "the juvenile brigades had begun to re-invest efforts to deal with delinquency following the [1998] report of Ms Christine Lazerges and Mr Jean-Pierre Balduyck" (Commission d'enquête sur la délinquance des mineurs, 2002). The central director for Public Security, when interviewed for the 2002 report, indicated that 109 juvenile brigades with an extended competence could now be found in 462 public safety districts. The French départements also have juvenile brigades, but the small number of police investigators restrict their work to the most serious cases. And lastly, the gendarmerie has no specialised service for minors.

The question of police specialisation in minors is under study: the movement is taking shape although it has yet to be thoroughly consolidated.

\subsection{Discretionary Powers of the Police}

The police do not have discretionary powers. When a minor is arrested he cannot be held in police custody without the agreement of the prosecutor's office ("parquet"). To avoid policy custody, the prosecutor occasionally asks the police to call the minor back for voluntary questioning. The prosecutor also has the right to decide whether the minor will be brought before him or not. $\mathrm{He}$ can ask the police to proceed with a "rappel à la loi", whereby the police officer informs the minor, with his parents present, of the sentence he can incur for the offence of which he is accused. If the minor does not have a police record and the charges are not serious, the prosecutor can also impose a settlement; this is accomplished by means of the judicial police officer. And lastly, in areas that have a community justice centre (maison de justice et du droit, MJD), the prosecutor can order the minor to be brought before the prosecutor's representative (see below). 


\subsection{Minors and Police Custody}

In principle, minors under the age of 13 cannot be held in police custody. One exception to this rule was expanded by the law of 9 September 2002: "On an exceptional basis, a minor of 10-13 years of age against whom there is serious or concordant evidence that he has committed or attempted to commit a serious felony or an offence punishable by at least five years imprisonment can, for the needs of the inquiry, be held in custody of a judicial police officer with the prior agreement and under the control of a prosecutor or an examining magistrate specialised in juvenile protection or a juvenile court judge, for a period determined by the prosecutor, but which cannot exceed twelve hours". This period can be extended for an additional twelve hours maximum. ${ }^{14}$

In all cases, the minor's parents must be informed at the very onset of the custodial sentence, unless there has been an exceptional decision by the public prosecutor or examining magistrate. If the minor is under 16 years of age, he must also be examined by a doctor. As soon as custody begins, the minor can request to speak to a lawyer and must be informed of this right. Police custody of a minor of 13-16 years of age cannot be extended if the offence is punishable by a sentence less than five years imprisonment.

Police custody of minors is under the control of the prosecutor. The exercise of this control can vary from one court to another. For example, a court in the Paris suburbs makes it mandatory for police investigators to contact the prosecutor on duty whenever they decide to place a minor in custody, even during the night. The prosecutor of this court also has established a custody inspection duty for the deputy prosecutors: they have to inspect the police register (indicating names, hours for the custody, times for the breaks, meals, hearings), the state of the custody cells, blankets, etc. These inspections have the added effect of enabling the deputy prosecutors to get to know the police investigators better as well as their working conditions.

\section{INTERVENTIONS OF THE PROSECUTOR}

The prosecutor's role in French juvenile justice has evolved noticeably. In order to fully appreciate this evolution, which cannot be reduced to replacing education

\footnotetext{
${ }^{14} \mathrm{~A}$ titre exceptionnel, le mineur de 10 à 13 ans contre lequel il existe des indices graves ou concordants laissant présumer qu'il a commis ou tenté de commettre un crime ou un délit puni d'au moins cinq ans d'emprisonnement peut, pour les nécessités de l'enquête, être retenu à la disposition d'un officier de police judiciaire avec l'accord préalable et sous le contrôle d'un magistrat du ministère public ou d'un juge d'instruction spécialisés dans la protection de l'enfance ou d'un juge des enfants, pour une durée que ce magistrat détermine et qui ne saurait excéder douze heures. The previous text stated: « indices graves et concordants », seven years imprisonment, ten hour in detention.
} 
by law enforcement measures, we need to summarise the structure of juvenile justice and the way it was practiced over many years. French juvenile court judges have a dual competence: criminal in the case of a delinquent minor, based on the ordinance of 2 February 1945, and civil when protecting a child in danger, based on articles 375 and following of the Civil Code. ${ }^{15}$ In both cases, the measures that the judge may impose are essentially educational: the 1945 ordinance gives priority to the educational measures over criminal sanctions, and affirms the right to education for delinquent minors. When the juvenile court was first set up, at the same time a directorate for Correctional Education (Direction de l'Education surveillée) was created to implement these educational measures. It is now called Directorate for Judicial Youth Protection (Direction de la Protection judiciaire de la jeunesse, PJJ). For many years juvenile court judges tended to open a file for educational assistance rather than a criminal file whenever possible, based on the idea that a young delinquent was above all a child in danger. Therefore, although the prosecutor has the legal power to launch criminal proceedings and oblige a minor to appear before a judge, until recently he actually seldom exercised this right. As for criminal files, due to the quasi-monopoly exercised by juvenile court judges coupled with the prosecutors' lack of interest in cases involving minors, their presence at hearings was often more a formality. The same held for lawyers, who were considered useless in this protection and guardianship perspective that only saw the interest of the child.

The prosecutor's low profile began to change about ten years ago, when the rise in petty and minor offences and the growing fear of crime led to a search for new forms of response: participation by agents other than those solely involved in public order. For their part, this latter group, especially the prosecutors, have also instituted new responses (see below). Nevertheless, the juvenile court judges are still involved throughout the whole process, they do not merely hand down a decision along the lines of traditional criminal justice.

\subsection{Prosecutor Specialisation}

Some courts have a special prosecutor for minors, others do not. This primarily depends on the size of the prosecutor's office (for practical reasons a "small" prosecutor's office with four deputy prosecutors cannot have a specialist in minors). However, it does not necessarily follow that all large prosecutor's offices have a specialised service for minors; this depends on the policy they adopt ${ }^{16}$. The

\footnotetext{
${ }^{15}$ "If the health, safety or morality of a non-emancipated minor are in danger, or if the conditions for his education are seriously compromised" (Si la santé, la sécurité ou la moralité d'un mineur non émancipé sont en danger, ou si les conditions de son éducation sont gravement compromises....).

${ }^{16}$ For example, Nanterre, a large office, does not have a "minors" specialisation, while Melun, "very medium sized", recently added a one, and Poitiers, a small office with 8 prosecutors, is trying to set up a specialisation thanks to a motivated deputy.
} 
current tendency is for a specialisation to develop: juvenile court judges appreciate the presence of prosecutors specialised in dealing with minors. They see them as privileged and habitual interlocutors who gain experience in working with minors and also know these youths personally, their background and evolution, just like the judges.

\subsection{Procedure to Launch Criminal Proceedings}

The prosecutor's office has a fair amount of leeway when deciding whether to send a minor before the court. The deputy prosecutor is the one who decides, in application of criminal justice policy. Guided by the police investigator, he considers how serious the charge is, the minor's record and personal situation, and other elements. In the case of criminal proceedings the judge can never bring charges against the minor on his own, unlike the educational assistance procedure where he himself can summon the minor before him.

New practices introduced by the prosecutors are components of what was originally called "proximity justice" (Wyvekens, 1998). In correctional law (for adults) and juvenile delinquency, the notion of employing mediation for petty crime, deemed to be better adapted to minor offences than criminal proceedings, progressively led to the prosecutors' practice for some offences of dropping a case if certain conditions were met. This "Praetorian practice" was set down in law in 1993 under the following terms: "The Public Prosecutor, the jurisdiction responsible for investigating a case, or the sentencing jurisdiction have the right to propose to a minor a measure or activity that assists or compensates the victim or is in the interest of the community." 17

This type of action can also take place earlier on, with the aim of prevention. The "Community Justice Centre" in Paris's $11^{\text {th }}$ arrondissement, for example, summons parents whose children the police have found several times loitering in the street late at night. This prosecutor's initiative enters into a broader partnership context where, if necessary, in addition to a warning, social services are also called in. Six months into the project, a drop in the number of children out "after hours" was observed. This experience gave rise to a debate: is this type of action still in the realm of the justice system or rather is it not social work? And do we have here an example of "penalising the poor", or rather the emergence of a "new response at the frontiers of social work"?

The prosecutor's office involvement in the form of conditionally dropping cases developed at the same time as another scheme called "real-time processing" of criminal cases. Whereas previously the police transmitted the files in writing to the prosecutor, where they were processed more or less rapidly, real-time processing consists in verbal reporting, by phone, as soon as police custody has ended. The (judicial) police officer calls the prosecutor, describes the case and

\footnotetext{
${ }^{17}$ New Art. $12-1$ of the ordinance of 2 February 1945.
} 
the prosecutor immediately advises on the follow-up to be given (proceedings by the prosecutor's office, transfer to the judge, etc.). In other words, this evolution combines in practice a diversity of responses with a quicker response.

In this train of events, in some prosecutor's offices at least, where practices can vary noticeably from one office to another - the prosecutor's role before the juvenile court has come to be more like the one foreseen by the law. Furthermore, the lawyer has also assumed his place, amidst a more general movement of increased attention to "children's rights".

\subsection{Probation}

Minors of 13-18 years of age can be put on probation under certain conditions. Depending on the case this is handled by the juvenile court judge, the examining magistrate or the "juge des libertés et de la détention" - the judge responsible for civil liberties and detention. The law of 9 September 2002 stipulated the obligations of a minor on probation: either to submit to measures of protection, assistance, supervision and education implemented by the Judicial Youth Protection Office or a licensed private facility; or - and this is one of the main novelties of this law - to respect the conditions for placement in an educational centre, in particular a closed educational centre (centre éducatif fermé, CEF), and this for a maximum period of six months, renewable once for another six months.

\subsection{Pre-trial Detention of Minors}

In the spirit of legal texts, pre-trial detention of minors, just like (or even more so) for their incarceration, is an exceptional measure. Even the latest amendment to the law in this area (the law of 9 September 2002) states this explicitly. This law foresees two distinct ways of extending the possibilities to detain minors before trial. The first is to broaden existing possibilities (pre-trial detention serving both to further the investigation and, in some cases, to "make a point"): minors at least 16 years old can henceforth be placed in pre-trial detention if under suspicion for an offence punishable by a prison term of three years or more (and not only for a serious criminal offence sentence). The second is a new possibility linked to a recent measure: placement in a closed educational centre (see below), a new form of placement in which the term "closed" refers precisely to the fact that the sanction for failure to respect this obligation (legally tantamount to judicial control) will be placing the minor in pre-trial detention in jail.

Pre-trial detention of minors is subject to various forms of control:

- By the rules of procedure themselves which limit this detention according to the minor's age and the seriousness of the charge

- By the jail's incarceration commission for minors

- By educators of the Judicial Youth Protection Office who follow the detained minors and report to the magistrates 
- By the lawyers who handle applications for release

- By the judge

As for the involvement of social or educational services, pre-trial detention is not principally the time for this work. A social-educational supervision is foreseen throughout the procedure, through the court's educational service (Service éducatif auprès du tribunal, SEAT) and "centres for educational action" (centres d'action éducative, CAE). ${ }^{18}$ The SEAT is responsible for providing guidance to juvenile delinquents under their jurisdiction and proposes educational solutions. The role of this service is to consult with the minors and their families, ensure the follow-up of incarcerated minors and perform the measures of liberté surveillée (a special form of probation for minors), community service, and reparation. The CAE's are responsible for investigations to assist the magistrate in his or her decision process. ${ }^{19}$ They are also responsible for the education of delinquent minors or minors in danger who continue to stay in their families. These centres are multidisciplinary; they work with the minor as well as with his social environment and his family. They are also responsible for implementing restitution measures applied to delinquent minors.

\section{SENTENCING AND SANCTIONS}

During the sentencing phase of a case, jurisdiction for minors has three different "faces". Once the court has made the necessary investigations (after referral by the prosecutor) the youth court magistrate can either judge the case in chambers, alone, only handing down educational measures, or he can send the case to the juvenile court. This is mandatory if the infraction would incur a sentence of seven years or more imprisonment. The juvenile court is composed of the youth court magistrate (who presides) and two assessors (non professional magistrates). This court primarily judges offences (délits) committed by minors or serious offences (crimes) committed by minors under 16. It can order educational measures or else a penalty. Lastly, serious offences committed by minors of 16-18 years of age are tried by the Juvenile Assize Court, composed of three professional magistrates (a chief magistrate and two assessors who are youth court magistrates of the court district) and a jury of citizens. This court can either order educational measures, or impose fines and prison sentences.

The issue of sanctions is subject to much current debate. After establishing (art. 1) that delinquent minors would be referred to a specialised jurisdiction, the ordinance of 2 February 1945 states (art. 2) that "the juvenile court and the juvenile assize court shall hand down, according to the case, the measures of protection,

\footnotetext{
${ }^{18}$ The SEAT and CAE are governed by the Judicial Youth Protection.

${ }^{19}$ Social Inquiries and measures of measures for investigation and education (enquêtes sociales et mesures d'investigation et d'orientation éducative, IOE).
} 
assistance, supervision and education deemed appropriate". Until 2002, the article was retained with one explicit exception to the principle: "They can, nevertheless, when the circumstances and the personality of the delinquent seem to so require, impose a penal sentence to a minor of over 13 years of age . ..". ${ }^{20}$

The word sanction did not appear until 2002, in the expression educational sanction. The second part of Art. 2 was amended to read: "They can, nevertheless . . . either impose an educational sanction for minors aged 10 to $18 \ldots$ or impose a penalty on minors from age 13 to age 18 taking into account their diminished criminal responsibility ..."

The expression "educational sanction" is essentially intended to enable the courts to apply a sanction to minors who have not reached the age of criminal responsibility (13 years) and who until the 2002 amendment escaped all punishment. The educational sanctions (art. 15-1) now applicable from the age of 10 include confiscating an item belonging to the minor and linked to the infraction, interdiction to frequent certain places or people (victims or co-authors of the infraction), the obligation to follow a civic training course, ${ }^{21}$ an assistance measure, and restitution.

Without going into too many details (applicability according to age, accumulation of offences), the measures that the juvenile jurisdiction can order, in addition to the so-called educational sanctions (applicable until the age of 18), are judicial protection (protection judiciaire), supervision (liberté surveillée), placement (in various types of living units), fines, ${ }^{22}$ community service work (minors of 16-18 years), control by electronic monitoring, a suspended incarceration sentence, and incarceration.

In the case of incarceration (art. 20-2), juvenile judges cannot impose a custodial sentence longer than half that of the sentence that would be incurred by an adult. And this can only be imposed in exceptional cases and only on minors over 16 years of age. Minors can only be incarcerated in a special prison section or in a specialised penal establishment for minors.

In addition to non-residential centres for educational action (centres d'action éducative en milieu ouvert), the Judicial Youth Protection Office manages various types of residential facilities. The secure educational centres (centres éducatifs renforcés, CER $)^{23}$ are adapted to the treatment of minors who are delinquent

\footnotetext{
${ }^{20}$ Art. 2 "le tribunal pour enfants et la cour d'assises des mineurs prononceront, suivant les cas, les mesures de protection, d'assistance, de surveillance et d'éducation qui sembleront appropriées." Until 2002: "Ils pourront cependant, lorsque les circonstances et la personnalité du délinquant leur paraîtront l'exiger, prononcer à l'égard du mineur âgé de plus de treize ans une condamnation pénale ..." 2002 Amendment : "Ils pourront cependant . . s soit prononcer une sanction éducative à l'encontre des mineurs de dix à dix-huit ans . . . soit prononcer une peine à l'encontre des mineurs de treize à dix-huit ans en tenant compte de l'atténuation de leur responsabilité pénale ...."

${ }^{21}$ A decree of 5 January 2004 organises this training.

${ }^{22}$ Not over half of the fine incurred by an adult, or not exceeding 7,500 euros.

23"Invented" in 1996, initially called "Unités à encadrement éducatif renforcé (UEER)". Presently 47 CER are operational.
} 
or seriously marginalised, and are in danger of recidivism and imprisonment". They work on "the danger of disintegration in an educational perspective". ${ }^{24}$ The objective is to "create, through the discovery of a new way of life outside their normal environment, the conditions capable of producing a transformation of their image of the adult world and life in society". The sessions last from 3 to 6 months, with a group of 5 to 7 youths. Emergency placement centres (centres de placement immédiat $\mathrm{CPI}){ }^{25}$ must be able to cope with emergency placements (3-4 months) of minors, in particular delinquents. The objective is both to put them in a situation that "breaks from the environment and lifestyle that led them before the court" and to enable the services involved to "evaluate the situation of the minor and elaborate proposals leading to long-term educational solutions". ${ }^{26}$ The guidance objective is thus more important than that of the final emergency placement. Closed educational centres (centres éducatifs fermés, CEF) are one of the main innovations of the law of 9 September 2002. They are addressed to minors of 13-18 years of age placed by judicial decision, either by a supervision order or under a conditional detention sentence, for a period of 6 months. The term "closed" should not be taken in the physical sense, as barred windows (such as politicians tend to convey), but refers to the fact that the placement is in the framework of judicial control and thus entails the threat of incarceration in prison if the youth attempts to escape from the centre. Eleven centres were operational in January 2005.

Lastly, we should note that since the Perben law of 2002 the juvenile judge ${ }^{27}$ can impose sanctions on parents: when summoned by the court, they are fined if they fail to appear.

\section{CONCLUSIONS}

The French juvenile justice system has undoubtedly been the subject of attempts to make it tougher, as way of answering to an increase in youth delinquency and to the consequences of it. Measures like the creation of closed educational centres seems to go in that direction and has been interpreted in that way. Similarly, in France as in other countries, an increase in prosecutor's power can be noticed which has given rise to concern about the double risk of more repressive answers and less protection to civil liberties. Those two examples can be read in another

\footnotetext{
${ }^{24}$ Source : web site of the Ministry of Justice - http://www.justice.gouv.fr

${ }^{25}$ Decided in 1999. Presently 37 have been set up.

${ }^{26} \mathrm{Ibid}$.

${ }^{27}$ The Criminal Code (Art. 227-17) punishes with two years prison and a 30000 euros fine the parents who heavily compromise the health, security, morality or education of their minor children (Le fait, par le père ou la mère légitime, naturel ou adoptif, de se soustraire, sans motif légitime, à ses obligations légales au point de compromettre gravement la santé,la sécurité, la moralité ou l'éducation de son enfant mineur est puni de deux ans d'emprisonnement et de 30000 euros d'amende.)
} 
way, less pessimistic. We would like to suggest, as an hypothesis to be confirmed (or not) by the evolution of practice, that an important part of the intention of the "Perben law" was to show to the opinion that the issue of juvenile delinquency really was addressed, not only through "soft" measures, but also around ideas like getting some places rid of the most harmful young delinquent. Thus the French law indeed has created "closed educational centers", but they are not closed with fences, and they are a place where to develop educational measures specific for young instead of locking them up in prison with adults. As for the evolution in the prosecutors' practice, it precisely shows that only the observation of what really happens in the field allows to qualify a trend. French prosecutors indeed have got more power within the juvenile justice system. But it was out of a concern for giving quicker answers and had as a result the implementation of more various diversion measures . . . by those prosecutors, and the comeback of the lawyer in the juvenile court.

\section{REFERENCES}

Aspects de la criminalité et de la délinquance constatées en France par les services de police et de gendarmerie (2003). Paris, La documentation Française.

Bègue, L. (2000). Attachements sociaux, croyances conventionnelles et délinquance, research report. Paris, IHESI.

Commission d'enquête sur la délinquance des mineurs (Commission of Inquiry into juvenile delinquency) (2001-2002). La République en quête de respect. Les Rapports du Sénat, n 340.

Commission des maires sur la sécurité (1982). Face à la délinquance : prévention, répression, solidarité. Paris, La Documentation française.

Délégation interministérielle à la Ville, département « Citoyenneté, prévention, sécurité » (Citizens, prevention, security) (2004). http://i.ville.gouv.fr/divbib/doc/prevention-delinquance.pdf

Lazerges, Ch. and Balduyck, J.-P. (1998). Réponses à la délinquance des mineurs, rapport au Premier Ministre, Paris, La Documentation Française.

Ministère de l'Education nationale, direction de la programmation et du développement (2003). note d'information $\mathrm{n}^{\circ} 03-07$, février.

Ministère de la Justice, direction de l'Administration générale et de l'Equipement, sous-direction de la Statistique, des études et de la documentation (2003). Les chiffres-clés de la justice.

Roché, S. (ed.) (2000). Enquête sur la délinquance autodéclarée des jeunes, research for the MAIF foundation, the Ministry of the Interior (IHESI), the Ministry of Justice (GIP « Droit et justice » et Protection judiciaire de la jeunesse), le Centre de prospective de la Gendarmerie nationale, la Semitag, Grenoble, CERAT.

Roché, S. (2001). La délinquance des jeunes. Les 13-19 ans racontent leurs délits. Paris, Seuil.

Wyvekens, A. (1998). Délinquance des mineurs: justice de proximité vs justice tutélaire, Esprit, March-April, pp. 158-173. 